\title{
Response of canola (Brassica napus L.) to exogenous application of nitrogen, salicylic acid and gibberellic acid under an arid climate
}

\author{
Muhammad Ijaz, Ahmad Sher ${ }^{1}$, Abdul Sattar ${ }^{1}$, Muhammad Shahid ${ }^{3}$,Ahmad Nawaz ${ }^{1}$, Sami Ul-Allah ${ }^{1 *}$, Muhammad \\ Tahir $^{2}$, Saqlain Ahmad ${ }^{1}$ and Muhammad Saqib ${ }^{4}$ \\ ${ }^{1}$ College of Agriculture, Bahauddin Zakariya University, Bahadur Sub-Campus, Layyah, Pakistan. \\ ${ }^{2}$ Department of Environmental Sciences, COMSATS Institute of Information Technology, Vehari, Pakistan. \\ ${ }^{3}$ Department of Bioinformatics and Biotechnology, Government College University, Faisalabad, Pakistan. \\ ${ }^{4}$ Department of Agronomy, University of Agriculture, Faisalabad.
}

\begin{abstract}
Sustainable improvement of yield under limited land resources is a challenge for future food security and types and techniques of fertilization are critical for this challenge. In this view, a 2-year study was conducted to investigate the interaction of nitrogen $(N)$ with salicylic acid and gibberellic acid on productivity and quality of canola (Brassica napus L.) during the year 2014-15 and 2015-16. The experiment was conducted in a split-plot arrangement of treatments where four $N$ levels $\left(60,80,100,120 \mathrm{~kg} \mathrm{ha} \mathrm{a}^{-1}\right)$, kept in main plots, and four levels of plant growth regulators PGRs [Control, salicylic acid (100 ppm), gibberellic acid (100 ppm) and combination of the two], kept in sub-plots, and replicated three times. The results indicated that combined application of $N$ and PGRs in either combination improved the morphological/yield parameters, seed yield and seed quality attributes of canola crop. The maximum seed yield of $2230 \mathrm{~kg} \mathrm{ha}^{-1}$ was recorded when $\mathrm{N}$ application @ $120 \mathrm{~kg} \mathrm{ha} a^{-1}$ interacted with combine application of salicylic acid and gibberellic acid. The combined application of gibberellic acid and salicylic acid enhanced the seed yield and seed oil contents of canola by 13.3-17.7\% and 28.9-29.8\%, respectively, than control treatment (no application of salicylic acid and gibberellic acid) during the both years of experimentation. Therefore, to combat emerging food security issues, combined application of salicylic acid and gibberellic acid along with $N$ (at 100/120 $\mathrm{kg} \mathrm{ha}^{-1}$ ) will be a practicable option to improve the productivity and quality of canola grown under arid climates.
\end{abstract}

Keywords: Canola nutrition, nitrogen, gibberellic acid, salicylic acid, oil contents, protein contents

\section{Introduction}

With limited resources of land and water, it is critical to produce sustainable agriculture. Regarding oil seed crops, Pakistan is ranked as the fourth largest importer of the edible oil in the world whose almost $75 \%$ edible oil demand is fulfilled through imports (Zaidi, 2014). Pakistan imports $\sim 1.8$ million tons of the edible oil of worth almost US\$ 1.4 billion each year (Government of Pakistan, 2015-16). This indicates that there is huge shortage of edible oil in the country which can only be fulfilled by using new techniques in agriculture.

Although, the crops such as mustard, sunflower and cotton contribute in the domestic production of edible oil; nonetheless their share is not enough to fulfill the edible oil needs of the population of the country (Zaidi, 2014). There are various factors which are responsible for low edible oil production in the country. Firstly, the oilseed crops are grown on a very small area and thus the overall oilseed production is not enough to extract the required quantity of the edible oil. Secondly, the oilseeds crops are grown on marginal lands due to which per acre yield of the oilseed crops is very low which further deteriorate this situation (Ali et al., 2014). Indeed, the planation period of the main oilseed crops (e.g. rapeseed and mustard) is the same as of other rabi crops (e.g. wheat, gram) and thus the farmers never compromise to sacrifice their main crops for oilseed crops. Thirdly, the insect pests (e.g. aphid) and diseases are also a hindrance in harvesting the optimum yield of oilseeds. Unwise use of fertilizers is also a major reason for low oilseed production in the country.

Among the oilseed crops, canola (Brassica napus L.) has emerged as an important oilseed crop in the world including Pakistan. However, the yield of canola is low in Pakistan due to poor nutrient management. Thus, to optimize the production of canola in the country, wise nutrient management strategies might be quite useful to boost up its production under arid and semi-arid environment.

*Email: sami_llh@yahoo.com 
The oilseed crops require adequate nitrogen $(\mathrm{N})$ supply for attaining the maximum productivity (Stahl et al., 2017; Gu et al., 2018). Thus, the improvement in $\mathrm{N}$ use efficiency of oilseed crop required the optimization of the rates of $\mathrm{N}$ fertilizer. Various factors such as the soil $\mathrm{N}$ supply and moisture fluctuations at the critical growth stages of oilseed crops may impact the $\mathrm{N}$ use efficiency.

Among the rapeseed species, the $\mathrm{N}$ requirement of canola is higher than others and it is considered as a high $\mathrm{N}$ demanding crop (Rathke et al., 2005; Stahl et al., 2017). Thus, it is critical to optimize the $\mathrm{N}$ application to exploit the full potential of canola crop. Indeed, $\mathrm{N}$ is an essential component of amino acids, the building blocks of proteins. $\mathrm{N}$ is also an integral part of the green pigments (e.g. chlorophyll) of all the plants and triggers the process of photosynthesis. The other roles of $\mathrm{N}$ in plants include its involvement in seed germination, leaf development and

\section{Materials and Methods}

\section{Experimental site and soil}

Two year experiment was carried out at the Agronomic Research Area, The Islamia University of Bahawalpur (longitude $71.4^{\circ} \mathrm{E}$, latitude $29^{\circ} \mathrm{N}$, and altitude 181 masl) during 2014-15 and 2015-16. Prior to sowing of canola crop, the soil samples (from $0-20 \mathrm{~cm}$ depth) were collected with the help of an auger. These soil samples were placed into tagged polythene bags and were sent to soil and water testing laboratory of the Regional Agriculture Research Institute (RARI) Bahawalpur for analysis. The soil analysis report of the experimental soil showed that the soil was loamy in texture with an average $\mathrm{pH}$ of 8.2-8.4, electrical conductivity of $247-250 \mu \mathrm{S} \mathrm{cm}$ c $^{-1}$, exchangeable sodium of $0.23-0.24 \%$, available phosphorus of 7-9 ppm, available potassium of $115-121 \mathrm{ppm}$, total $\mathrm{N}$ of $0.05-0.08 \%$ and

Table 1: Rainfall and temperature data during the study period

\begin{tabular}{|c|c|c|c|c|c|c|}
\hline & \multicolumn{4}{|c|}{ Temperature $\left({ }^{\circ} \mathbf{C}\right)$} & \multicolumn{2}{|c|}{ Rainfall (mm) } \\
\hline & \multicolumn{2}{|c|}{ Maximum } & \multicolumn{2}{|c|}{ Minimum } & \multirow[b]{2}{*}{ 2014-15 } & \multirow[b]{2}{*}{ 2015-16 } \\
\hline & $2014-15$ & $2015-16$ & 2014-15 & 2015-16 & & \\
\hline November & 32.4 & 31.8 & 9.7 & 9.9 & 0.00 & 0.00 \\
\hline December & 25.5 & 28.0 & 1.7 & 2.5 & 0.00 & 0.00 \\
\hline January & 24.3 & 26.0 & 2.2 & 1.9 & 0.00 & 0.00 \\
\hline February & 27.5 & 33.1 & 6.9 & 5.5 & 16.5 & 4.20 \\
\hline March & 38.2 & 37.5 & 8.1 & 12.3 & 24.4 & 29.7 \\
\hline
\end{tabular}

flower/fruit development (Kumar et al., 2018; Saini et al., 2017).

Likewise, the use of plant growth regulators (PGRs) viz. cytokinin, salicylic acid, and abscisic acid is very useful for improving the crop growth under optimal and suboptimal conditions (Farooq et al., 2009; Upreti and Maryada, 2016). Among these, the role of salicylic acid in multiple physiological processes of plants including growth, nutrient uptake, flower induction, stomatal movements, enzyme activities and photosynthesis is well-known (Hayat et al., 2007). On the other hand, gibberellic acid is also an important growth regulator which affects the growth and yield (Rafeekher et al., 2002), through positive influence on stem and internode elongation, seed germination, enzyme activation and fruit setting (Hussain et al., 2018).

As the oilseeds are mostly grown under arid and semiarid climates in Pakistan without any supplemental irrigation, it was hypothesized that the salicyclic and gibberellic acid may interact with $\mathrm{N}$ to improve the seed yield and quality of canola. Thus, major objective of the study was to check the interactive effect of $\mathrm{N}$ with salicylic acid and gibberellic acid on growth, seed yield and seed quality of canola. saturation percentage of 35-37\% during both years. Data on temperature and rainfall during both experimental sites during the growth period is given in Table 1 .

\section{Experimental design and treatments}

The experiment was laid out in randomized complete block design, in split plot arrangement with a net plot size of $2 \mathrm{~m} \times 3 \mathrm{~m}$. The experiment comprised of four $\mathrm{N}$ levels [120 (high), 100 (recommended), 80 (medium) and 60 (low) $\mathrm{kg}$ $\mathrm{ha}^{-1}$, kept in main plots, and four PGRs treatments viz., salicylic acid (100 ppm), gibberellic acid (100 ppm), salicylic acid + gibberellic acid; no PGRs application being taken as control. The foliar application of PGRs was made twice, at 30 and 45 days after sowing. Hyola 433 was used as tested canola hybrid in this study.

\section{Seedbed preparation, sowing and crop husbandry}

Before sowing of canola crop in each year, field was irrigated to bring the soil at field capacity. When the soil reached at workable soil moisture, the seed bed was prepared through 3 cultivations (using tractor mounted cultivator up to depth of $0.20 \mathrm{~m}$ ), which was followed by a 
single planking with wooden planker. The canola crop was sown on November 02 and November 05 during 2014 and 2015 , respectively. The canola crop was seeded at $5 \mathrm{~kg} \mathrm{ha}^{-1}$ in $75 \mathrm{~cm}$ apart rows with the help of a locally manufactured manual hand drill. After uniform emergence, the thinning was carried out to maintain the plant to plant distance of 15 $\mathrm{cm}$. On the basis of soil analysis report, synthetic fertilizers were applied at the rate of $60: 50 \mathrm{~kg} \mathrm{P}_{2} \mathrm{O}_{5}$ and $\mathrm{K}_{2} \mathrm{O}$, respectively using the diammonium phosphate (46\% $\mathrm{P}, 18 \%$ $\mathrm{N})$ and sulphate of potash $\left(50 \% \mathrm{~K}_{2} \mathrm{O}\right)$ as sources of $\mathrm{P}$ and $\mathrm{K}$, respectively. Full dose of $\mathrm{P}$ and $\mathrm{K}$ was applied at sowing time. Half of the $\mathrm{N}$ [using urea $(46 \% \mathrm{~N})$ as source] from each treatment was used as basal dose; the remaining $\mathrm{N}$ in each treatment was splitted into two halves (applied with first and second irrigation). The $\mathrm{N}$ available from diammonium phosphate was added to each treatment when applying the urea in each experimental $\mathrm{N}$ treatment. In total, four irrigations (each of 3 acre inches) were applied to canola crop during each year. The first irrigation was done 21 days after emergence. The second, third and fourth irrigations were applied at vegetative, head formation, and seed filling stages, respectively. The irrigation was stopped one week prior to harvesting at physiological maturity. The weeds within the experimental plots were removed through manual weeding. All the other agronomic practices and plant protection measures were adopted uniformly in all the plots to keep the crop healthy and free of insects and diseases.

\section{Harvesting and data recording}

\section{Morphological and yield parameters}

Data on morphological (plant height, leaf area index, primary/secondary branches per plant), yield parameters (plant population, 1000-seed weight, seeds per siliqua, siliqua per plant, seed yield, seed oil and protein contents were recorded following the standard procedures. The final plant population was counted from a unit area (measuring 1 $\mathrm{m} \times 1 \mathrm{~m})$ at harvest from two locations of each experimental plot and was averaged. The plant height of ten plants (randomly selected) from each of the experimental plot was recorded from soil surface to the tip of plant with the help of a meter rod, and then averaged. The leaf area was measured at fifteen days by using a leaf area meter. The sampling for leaf area measurement was started twenty days after sowing (DAS) until crop harvest. After that, the leaf area index was calculated by using the formula given by Watson (1947). The number of primary and secondary branches of ten randomly selected plants from each of the experimental plots were counted, averaged and were reported separately as primary and secondary branches. At harvest maturity, the number of siliquas from ten randomly selected plants were counted and then averaged to work out number of siliquas per plant. Twenty five siliques were randomly taken from five randomly selected plants from each plot and their seeds were counted.

The canola crop was harvested at harvest maturity (on April 18, 2015 and April 20, 2016) when the pods were turned from green to yellowish brown. The whole plants within an experimental plot were harvested using a locally manufactured hand sickle and the samples were left in the field for a week for sun-drying. After sun-drying, the crop samples were threshed manually to separate the seeds from stover. These seeds were weighed on an electric balance separately for each experimental plot and the seed yield was converted to $\mathrm{kg} \mathrm{ha}^{-1}$.

The 1000-seed weight was estimated after collecting three random samples of 1000 seeds from seed lot of each treatment, which were weighed on an electrical balance to find the 1000-seed weight.

\section{Quality parameters}

For protein determination, the $\mathrm{N}$ contents within the canola seeds were determined by Kjeldhal method (Bremner, 1964) followed by the determination of crude proteins with following formula:

Crude protein $(\%)=\frac{(V 1-V 2) N \times 14 \times 6.25 \times 100}{100 \mathrm{~W}}$

The seed oil contents were measured by the Soxhlet Fat Extraction method (AOAC, 1990). The oil content was calculated as following:

oil $(\%)=\frac{\text { Weight of flask }+ \text { oil }- \text { Weight of flask } \times 100}{\text { Weight of flask }+ \text { seed }- \text { Weight of flask }}$

\section{Statistical analysis}

The data collected for each parameter was manually entered in the Microsoft excel sheet followed by its analysis through the statistical software "Statistics 8.1" by using the Fischer analysis of variance technique (Steel et al., 1997). The differences in the significant treatments means were then estimated by least significant difference test at $5 \%$ probability level.

\section{Results}

\section{Morphological and yield parameters}

This study indicated that $\mathrm{N}$ application at variable rates significantly improved the seeds per silique during both years, 1000-seed weight for first year, number of silique per plant and seed yield during the second year; results being nonsignificant for the remaining studied traits. Likewise, the application of PGRs significantly increased the leaf area index, primary/secondary branches, plant height, silique per 
plant, seeds per silique, 1000-seed weight and seed yield during the both year of experimentation; results being nonsignificant for plant population during the both years. The interaction of $\mathrm{N}$ application with PGRs was only significant for primary branches and 1000-seed weight for first year and number of seeds per silique for second year (Tables 2, 3).

The highest siliques per plant as well as the seed yield during the second year, and the seeds per silique during the that was statistically similar with the sole application of gibberellic acid for the secondary branches, and with the sole application of gibberellic acid and salicylic acid for 1000-seed weight during the year 2015-16 (Tables 2, 3). Combined application of gibberellic acid and salicylic acid enhanced the canola seed yield by $13.3-17.6 \%$ during both years (Table 3).

The interactive effect showed that significantly higher

Table 2: Influence of nitrogen application at variable rates in combination with plant growth regulators on allometric, morphological and yield parameters of canola

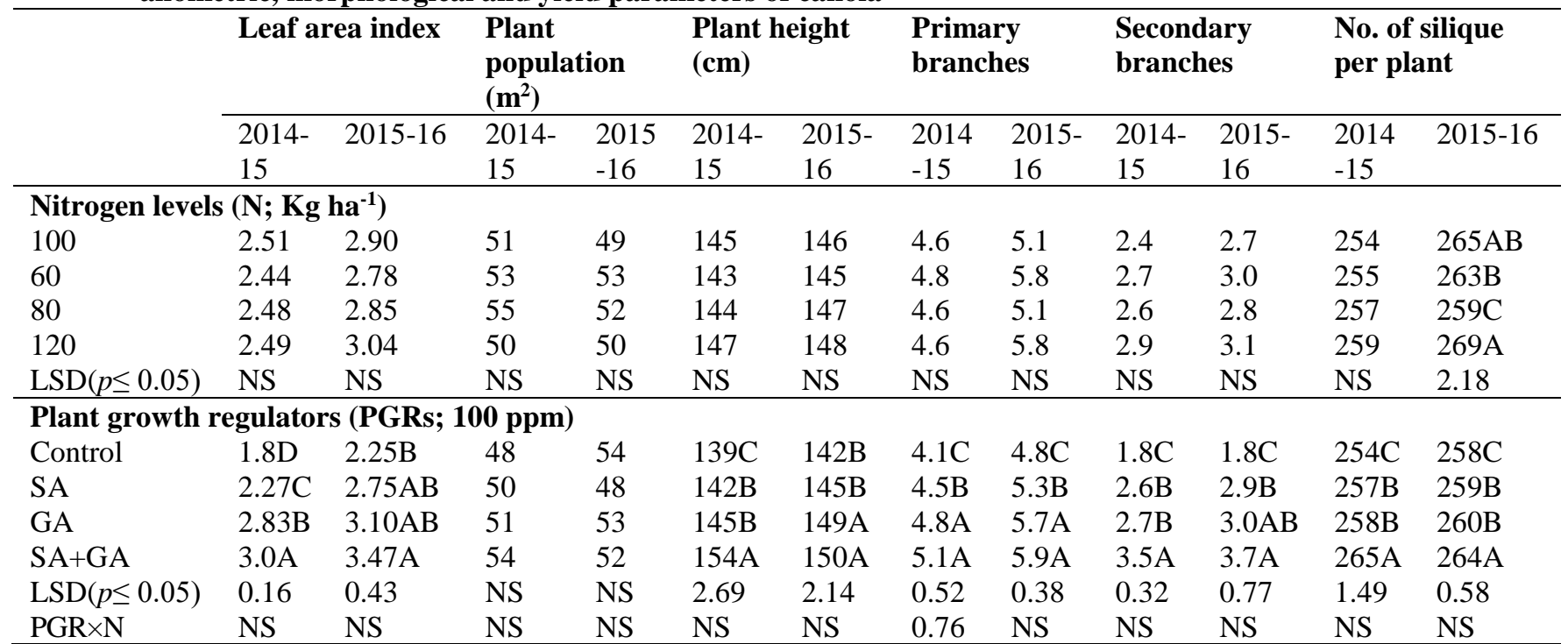

Means of nitrogen and plant growth regulators sharing the same letter, do not differ significantly at $\mathrm{p} \leq 0.05$; $\mathrm{SA}=\mathrm{Salicylic}$ acid; GA= Gibberellic acid; NS= non-significant

both years were recorded with $\mathrm{N}$ application at the rate of $120 \mathrm{~kg} \mathrm{ha}^{-1}$ and they were statistically similar with the $\mathrm{N}$ application at the rate of $100 \mathrm{~kg} \mathrm{ha}^{-1}$ (Tables 2, 3). Application of $\mathrm{N}$ at 80,100 and $120 \mathrm{~kg} \mathrm{ha}^{-1}$ was equally effective for improvement in 1000-seed weight during the year 2014-15 (Table 3).

Among the PGRs, the highest leaf area index and plant height was recorded with the combined foliage application of gibberellic acid and salicylic acid during both years and that was statistically similar with sole application of gibberellic acid and salicylic acid for leaf area index and gibberellic acid for plant height during the year 2015-16 (Table 2). Sole application of gibberellic acid and combined foliage application of gibberellic acid and salicylic acid was equally effective for the improvement in the primary branches per plant during the both years of experimentation (Table 2). The highest secondary branches per plant, 1000seed weight, seeds per silique, siliquas per plant, and seed yield was recorded with the combined foliage application of gibberellic acid and salicylic acid during both years, and number of silique per plant and seed yield for second year and number of seeds per silique during the both years were recorded with combined application of PGRs with $\mathrm{N}$ application@120 kg ha-1 (Tables 2, 3). The interactive effect also showed that significantly higher 1000-seed weight for first year was recorded with combined application of PGRs with N application @ 120, 80 and 100 $\mathrm{kg} \mathrm{ha}^{-1}$, respectively (Table 3 ).

\section{Quality parameters}

Application of $\mathrm{N}$ at variable rates did not significantly affect the seed oil contents and seed protein contents. However, foliar application of PGRs significantly affected the seed oil contents and seed protein contents during both years of experimentation. The interaction of $\mathrm{N}$ application with PGRs was only significant for seed oil contents during the year 2014-15 (Table 3). Among the PGRs, the highest seed oil contents were recorded with the combined foliar application of gibberellic acid and salicylic acid during the year 2014-15 and 2015-16 (Table 3). Combined foliage 
application of gibberellic acid and salicylic acid enhanced the seed oil contents by $28.9-29.8 \%$ than control treatment during the both years of experimentation. However, the seed protein contents were higher where no growth regulator was applied (Table 3 ). dry matter yield. Better stay green eventually results in better assimilates translocation during the reproductive and grain filling stages thus improving the number of silique per plant (Table 2, 3; Khorshidi et al., 2013), seeds per silique (Table 3; Khorshidi et al., 2013), and 1000-seed weight

Table 3: Influence of nitrogen application at variable rates in combination with plant growth regulators on morphological/yield parameters, seed yield, seed oil contents and seed protein contents of canola

\begin{tabular}{|c|c|c|c|c|c|c|c|c|c|c|}
\hline & \multicolumn{2}{|c|}{$\begin{array}{l}\text { No. of seeds per } \\
\text { silique }\end{array}$} & \multicolumn{2}{|c|}{$\begin{array}{l}\text { 1000-seed weight } \\
\text { (g) }\end{array}$} & \multicolumn{2}{|c|}{ Seed yield $\left(\mathrm{kg} \mathrm{ha}^{-1}\right)$} & \multicolumn{2}{|c|}{$\begin{array}{l}\text { Seed oil } \\
\text { contents }(\%)\end{array}$} & \multicolumn{2}{|c|}{$\begin{array}{l}\text { Seed protein } \\
\text { contents }(\%)\end{array}$} \\
\hline & $2014-15$ & $2015-16$ & $2014-15$ & $2015-16$ & $2014-15$ & $2015-16$ & $\begin{array}{l}2014- \\
15\end{array}$ & $\begin{array}{l}2015- \\
16\end{array}$ & $\begin{array}{l}2014- \\
15\end{array}$ & $\begin{array}{l}2015- \\
16\end{array}$ \\
\hline \multicolumn{11}{|c|}{ Nitrogen levels $\left(\mathrm{N} ; \mathrm{Kg} \mathrm{ha}^{-1}\right)$} \\
\hline 100 & $26.9 \mathrm{AB}$ & $28.3 \mathrm{AB}$ & $3.50 \mathrm{~A}$ & 3.60 & 2031 & $2101 \mathrm{~A}$ & 34.8 & 33.9 & 19.6 & 20.8 \\
\hline 60 & $26.6 \mathrm{BC}$ & $27.6 \mathrm{~B}$ & $3.28 \mathrm{~B}$ & 3.92 & 2047 & 2072B & 34.5 & 34.0 & 19.2 & 20.4 \\
\hline 80 & $25.8 \mathrm{C}$ & $26.4 \mathrm{C}$ & $3.53 \mathrm{~A}$ & 3.91 & 2085 & 2077B & 35.1 & 34.0 & 19.5 & 20.9 \\
\hline 120 & $27.7 \mathrm{~A}$ & $29.3 \mathrm{~A}$ & $3.51 \mathrm{~A}$ & 4.05 & 2056 & $2110 \mathrm{~A}$ & 35.5 & 34.1 & 19.8 & 21.5 \\
\hline $\operatorname{LSD}(p \leq 0.05)$ & 1.02 & 0.54 & 0.18 & NS & NS & 20.0 & NS & NS & NS & NS \\
\hline \multicolumn{11}{|c|}{ Plant growth regulators (PGR; 100 ppm) } \\
\hline Control & 25.1D & $26.5 \mathrm{C}$ & $2.90 \mathrm{D}$ & $3.08 \mathrm{~B}$ & $1868 \mathrm{D}$ & 1953D & $30.5 \mathrm{D}$ & $29.8 \mathrm{D}$ & $22.8 \mathrm{~A}$ & $24.4 \mathrm{~A}$ \\
\hline SA & $26.2 \mathrm{C}$ & $27.1 \mathrm{C}$ & $3.37 \mathrm{C}$ & $3.81 \mathrm{AB}$ & $2037 \mathrm{C}$ & $2058 \mathrm{C}$ & $33.2 \mathrm{C}$ & $32.5 \mathrm{C}$ & $21.2 \mathrm{~B}$ & $22.4 \mathrm{~B}$ \\
\hline GA & $27.2 \mathrm{~B}$ & 28.3B & $3.63 \mathrm{~B}$ & $4.02 \mathrm{AB}$ & 2120B & 2141B & $36.5 \mathrm{~B}$ & $35.3 \mathrm{~B}$ & $18.9 \mathrm{C}$ & $20.1 \mathrm{C}$ \\
\hline $\mathrm{SA}+\mathrm{GA}$ & $28.5 \mathrm{~A}$ & $29.7 \mathrm{~A}$ & $3.92 \mathrm{~A}$ & $4.56 \mathrm{~A}$ & 2197A & $2213 A$ & $39.6 \mathrm{~A}$ & $38.4 \mathrm{~A}$ & 15.7D & 16.7D \\
\hline LSD $(p \leq 0.05)$ & 0.70 & 1.11 & 0.15 & 0.46 & 33.0 & 36.7 & 0.08 & 0.72 & 0.69 & 0.73 \\
\hline $\mathrm{PGR} \times \mathrm{N}$ & NS & 1.09 & 0.30 & NS & NS & NS & 0.17 & NS & NS & NS \\
\hline
\end{tabular}

Means of nitrogen and plant growth regulators sharing the same letter, do not differ significantly at $\mathrm{p} \leq 0.05$; $\mathrm{SA}=\mathrm{Salicylic}$ acid; $\mathrm{GA}=$ Gibberellic acid; NS= non-significant.

\section{Discussion}

The response of oilseed crops to soil applied $\mathrm{N}$ fertilizer is positive even at high rates as it is required for harvesting the maximum productivity (Stahl et al., 2017; Gu et al., 2018). As the oilseed crops are grown on marginal lands (deficient in macro and micronutrients) under semi-arid and arid environments, the $\mathrm{N}$ application becomes vital to harvest better seed yields. The nitrogen requirement of canola is higher than the other oilseed crops and considered as a high $\mathrm{N}$ demanding crop (Rathke et al., 2005; Pan et al., 2016; Ma and Zheng et al., 2016). Thus, it is critical to optimize the $\mathrm{N}$ application to exploit the full potential of canola crop under arid and semi-arid regions.

In the current study, $\mathrm{N}$ application significantly influenced some of the yield parameters (seeds per siliqua and siliquas per plant) of canola; and they were the maximum when $\mathrm{N}$ was applied at 120 or $100 \mathrm{~kg} \mathrm{ha}^{-1}$ than that of $\mathrm{N}$ application at low rates (60 and $80 \mathrm{~kg} \mathrm{ha}^{-1}$ ). Indeed, $\mathrm{N}$ is required for protein synthesis, leaf development, flower/fruit development, and is a part of chlorophyll (Kumar et al., 2018; Saini et al., 2017; Ul-Allah et al., 2015) thus imparts the stay green and finally improves the vegetative growth of crops. This improvement in vegetative growth of the plants ultimately increases the
(Table 3), as the same was observed in this study. In oilseed crops, the 1000-seed weight, seeds per silique and silique per plant are the main yield contributing traits. Thus, the improvement in these yield parameters due to application of $\mathrm{N}$ at higher rates resulted in highest seed yield. Low seed yield at the lower $\mathrm{N}$ application rates might be attributed to lower 1000-seed weight, silique per plant, seeds per silique (Tables 2, 3).

Beside macronutrients, PGRs (e.g., salicylic acid, cytokinin, gibberellins and abscisic acid) helps the plants to perform better under optimal and suboptimal conditions (Farooq et al., 2009; Khan et al., 2015; Siddiqui et al., 2016) than the plants not supplied with these PGRs. On the other hand, gibberellic acid is an important PGR that may improve the growth cascades of plants by stimulating the stem and internode elongation, enzyme activation, and the fruit setting (Colebrook et al., 2014; Dar et al., 2015), thus improving the yield parameters. Indeed, the PGRs divert the photosynthate towards the harvested product thus enhancing the actual productivity (Table 3; Abdelgadira et al., 2010). Seemingly, the combined foliage application of both PGRs improved the allometric and morphological parameters which resulted in better seed formation which was visible through improvement in 1000-seed weight and seeds per 
silique (Hayat et al., 2007; Mijic et al., 2006). Better yield parameters thus resulted in better seed yield in this study (Table 3).

Although $\mathrm{N}$ application did not significantly affect the seed oil and seed protein contents, the combined application of both PGRs significantly enhanced the seed oil contents and reduced the seed protein contents. Improvement in seed oil composition can be attributed to the activation of the synthesis of various enzymes which are involved in the metabolism of fatty acids (Talaat and EL-Din, 2007; Colebrook et al., 2014; Dar et al., 2015), thus enhancing seed oil contents as was observed in this study. However, seed protein contents were decreased due to sole or combined application of PGRs. Indeed, the oil contents follow reverse order against the protein content sin most oilseed crops (Bellaloui et al., 2015). As, the oil contents were enhanced due to exogenous application of PGRs, thus the protein contents were decreased.

\section{Conclusion}

In conclusion, combined application of gibberellic acid and salicylic acid enhanced the morphological and yield parameters which eventually enhanced the seed yield, seed oil contents and decreased the seed protein contents. Application of $\mathrm{N}$ at higher rates was most beneficial for improvement in yield parameters and seed yield than its application at low levels. The interactive effect showed that significantly higher number of silique per plant, number of seeds per silique and seed yield were recorded with combined application of gibberellic acid and salicylic acid with N application @ $120 \mathrm{~kg} \mathrm{ha}^{-1}$.

\section{References}

Abdelgadira, H.A., A.K. Jäger, S.D. Johnsonb and J.V. Stadena. 2010. Influence of plant growth regulators on flowering, fruiting, seed oil content, and oil quality of Jatropha curcas. South African Journal of Botany 76: 440-446.

Ali, B., P. Qian, and R. Jin. 2014. Physiological and ultrastructural changes in Brassica napus seedlings induced by cadmium stress. Biologia Plantarum 58: 131-138.

AOAC, 1990. Official methods of analysis, $15^{\text {th }}$ Ed. Association of official analytical chemists, Arlington, VA.

Bellaloui, N., H.A. Bruns, H.K. Abbas, A. Mengistu, D.K. Fisher and K.N. Reddy. 2015. Agricultural practices altered soybean seed protein, oil, fatty acids, sugars, and minerals in the Midsouth USA. Frontiers in Plant Science 6: 31-31.
Bremner, J.M. 1964. Organic form of nitrogen. p.12351255 In: Methods of soil analysis, part-2, C.A. Black (ed). American Society of Agronomy. Inc. Medison, Wisconsin, USA.

Colebrook, E.H., S.G. Thomas, A.L. Phillips and P. Hedden. 2014. The role of gibberellin signalling in plant responses to abiotic stress. Journal of Experimental Biology 217: 67-75.

Dar, T.A., M. Uddin, M.M.A. Khan, A. Ali, N. Hashmi and M. Idrees. 2015. Cumulative effect of gibberellic acid and phosphorus on crop productivity, biochemical activities and trigonelline production in Trigonella foenum-graecum L. Cogent Food \& Agriculture 1: 114.

Farooq, M., S.M. Basra, A. Wahid, N. Ahmad and B.A. Saleem. 2009. Improving the drought tolerance in rice (Oryza sativa L.) by exogenous application of salicylic acid. Journal of Agronomy and Crop Science 195: 237246.

Government of Pakistan, 2015-16. Agricultural Statistics of Pakistan. Ministry Food and Agricultural Division (Planning Unit), Islamabad, Pakistan.

Gu, X.B., Y.N. Li and Y.D. Du. 2018. Effects of ridgefurrow film mulching and nitrogen fertilization on growth, seed yield and water productivity of winter oilseed rape (Brassica napus L.) in Northwestern China. Agric. Agricultural Water Management 200: 60-70.

Hayat, Q., S. Hayat, M. Irfan, and A. Ahmad. 2010. Effect of exogenous salicylic acid under changing environment: a review. Environmental and Experimental Botany 68: 14-25.

Hussain, M., S. Farooq, W. Hasan, S. Ul-Allah, M. Tanveer, M. Farooq and A. Nawaz. 2018. Drought stress in sunflower: Physiological effects and its management through breeding and agronomic alternatives. Agricultural Water Management 201: 152-166.

Khan, M.I.R., M. Fatima, T.S. Per, N.A. Anjum and N.A. Khan. 2015. Salicylic acid-induced abiotic stress tolerance and underlying mechanisms in plants. Frontiers in Plant Science 6: 462.

Khorshidi, M.G., S. Moradpoor, A. Ranji, B. Karimi and F. Asri. 2013. Effect of different levels of nitrogen fertilizer and plant density on yield and yield components of canola. Scientific Journal of Crop Science 4: 2896-2900.

Kumar, K., Y. Kumar and N.K. Katiyar. 2018. Effect of plant geometry, nitrogen level and antitranspirants on physiological growth, yield attributes, WUE and economics of mustard (Brassica juncea) under semiarid conditions of western Uttar Pradesh. Journal of Pharmacognosy and Phytochemistry 7: 226-229. 
Ma, B.L. and Z.M. Zheng. 2016. Relationship between plant nitrogen and phosphorus accumulations in a canola crop as affected by nitrogen management under ample phosphorus supply conditions. Canadian Journal of Plant Science 96: 853-866.

Mijic, A., M. Krizmanić, V. Guberac and S. Marić. 2006. Stabilnost prinosa ulja nekoliko OS hibrida suncokreta. Poljoprivreda 12: 510.

Pan, W.L., M. McClellan, W.A. Hammac, V.A. McCracken, and R.T. Koenig. 2016. Mitscherlich-modeled, semiarid canola nitrogen requirements influenced by soil nitrogen and water. Agronomy Journal 108: 884-894.

Rafeekher, M., S.A. Nair, P.N. Sorte, G.P. Hatwal and P.N. Chandhan. 2002. Effect of growth regulators on growth and yield of summer cucumber. Journal of Soils \& Crops 12: 108-110.

Rathke, G.W., O. Christen and W. Diepenbrock. 2005. Effects of nitrogen source and rate on productivity and quality of winter oilseed rape (Brassica napus L.) grown in different crop rotations. Field Crops Research 94: 103-113.

Saini, L.B., P.J. George and S.S. Bhadana. 2017. Effect of nitrogen management and biofertilizers on growth and yield of rapeseed (Brassica campestris var. toria). International Journal of Current Microbiology and Applied Sciences 6: 2652-2658.

Siddiqui, M.A., Z.H. Shah, S. Tunio and Q. Chacchar. 2016. Effect of different nitrogen $(\mathrm{N})$ phosphorus $(\mathrm{P})$ fertilizer and plant growth regulators gibberellic acid (GA3) and indole-3-acetic acid (IAA) on qualitative traits of Canola (Brassica napus L.) genotypes. International Journal of Pure \& Applied Bioscience 4: 238-244.
Stahl, A., M. Pfeifer, M. Frisch, B. Wittkop, and R.J. Snowdon. 2017. Recent genetic gains in nitrogen use efficiency in oilseed rape. Frontiers in Plant Science 8: 963.

Steel, R.G.D., J.H. Torrie and D.A. Dickey. 1997. Principles and Procedures of Statistics: A Biometric Approach. 3rd Ed. McGraw Hill Book Co. Inc., New York, USA.

Talaat, I.M. and K.M. Gamal el-din. 2007. Physiological effect of putrescine and heat hardening on (Nigella sativa L) plants. International Journal of Agriculture and Biology 7:358-362.

Ul-Allah, S., A.A. Khan, T. Fricke, A. Buerkert and M. Wachendorf. 2015. Effect of fertiliser and irrigation on forage yield and irrigation water use efficiency in semiarid regions of Pakistan. Experimental Agriculture 51: 485-500.

Upreti, K.K., and M. Sharma. 2016. Role of Plant Growth Regulators in Abiotic Stress Tolerance. p. 19-46. In: Abiotic Stress Physiology of Horticultural Crops. N.K.S. Rao, K.S. Shivashankara and R.H. Laxman (eds.). Springer, New Delhi.

Watson, D.J. 1947. Comparative physiological studies on the growth of field crops: I. Variation in net assimilation rate and leaf area between species and varieties and within and between years. Annals of Botany 11: 41-76.

Zaidi, S.M.H. 2014. Edible oil imports in Pakistan. South Asian Journal of Management Sciences 1: 1-8. 